\title{
Front Matter: Volume 7703
}

, "Front Matter: Volume 7703," Proc. SPIE 7703, Independent Component Analyses, Wavelets, Neural Networks, Biosystems, and Nanoengineering VIII, 770301 (12 April 2010); doi: 10.1117/12.862966 Event: SPIE Defense, Security, and Sensing, 2010, Orlando, Florida, United
States 


\section{PROCEEDINGS OF SPIE}

\section{Independent Component Analyses, Wavelets, Neural Networks, Biosystems, and Nanoengineering VIII}

Harold H. Szu

F. Jack Agee

Editors

7-9 April 2010

Orlando, Florida, United States

Sponsored and Published by

SPIE

Volume 7703 
The papers included in this volume were part of the technical conference cited on the cover and title page. Papers were selected and subject to review by the editors and conference program committee. Some conference presentations may not be available for publication. The papers published in these proceedings reflect the work and thoughts of the authors and are published herein as submitted. The publisher is not responsible for the validity of the information or for any outcomes resulting from reliance thereon.

Please use the following format to cite material from this book:

Author(s), "Title of Paper," in Independent Component Analyses, Wavelets, Neural Networks, Biosystems, and Nanoengineering VIII, edited by Harold H. SzU, F. Jack Agee, Proceedings of SPIE Vol. 7703 (SPIE, Bellingham, WA, 2010) Article CID Number.

ISSN 0277-786X

ISBN 9780819481672

Published by

SPIE

P.O. Box 10, Bellingham, Washington 98227-0010 USA

Telephone +1 3606763290 (Pacific Time) · Fax +1 3606471445

SPIE.org

Copyright (C) 2010, Society of Photo-Optical Instrumentation Engineers

Copying of material in this book for internal or personal use, or for the internal or personal use of specific clients, beyond the fair use provisions granted by the U.S. Copyright Law is authorized by SPIE subject to payment of copying fees. The Transactional Reporting Service base fee for this volume is $\$ 18.00$ per article (or portion thereof), which should be paid directly to the Copyright Clearance Center (CCC), 222 Rosewood Drive, Danvers, MA 01923. Payment may also be made electronically through CCC Online at copyright.com. Other copying for republication, resale, advertising or promotion, or any form of systematic or multiple reproduction of any material in this book is prohibited except with permission in writing from the publisher. The CCC fee code is 0277-786X/10/\$18.00.

Printed in the United States of America.

Publication of record for individual papers is online in the SPIE Digital Library.

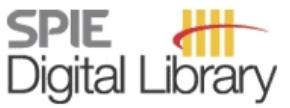

SPIEDigitalLibrary.org

Paper Numbering: Proceedings of SPIE follow an e-First publication model, with papers published first online and then in print and on CD-ROM. Papers are published as they are submitted and meet publication criteria. A unique, consistent, permanent citation identifier (CID) number is assigned to each article at the time of the first publication. Utilization of CIDs allows articles to be fully citable as soon they are published online, and connects the same identifier to all online, print, and electronic versions of the publication. SPIE uses a six-digit CID article numbering system in which:

- The first four digits correspond to the SPIE volume number.

- The last two digits indicate publication order within the volume using a Base 36 numbering system employing both numerals and letters. These two-number sets start with 00, 01, 02, 03, 04, $05,06,07,08,09,0 A, 0 B \ldots 0 Z$, followed by 10-1Z, 20-2Z, etc.

The CID number appears on each page of the manuscript. The complete citation is used on the first page, and an abbreviated version on subsequent pages. Numbers in the index correspond to the last two digits of the six-digit CID number. 


\section{Contents}

vii Conference Committee

xi Introduction

\section{WAVELET PIONEER AWARD}

770302 Detection and classification of virus from electron micrograms (Invited Paper) [7703-01] J.-O. Strömberg, Royal Institute of Technology (Sweden)

\section{WAVELETS APPLICATIONS I}

770303 SERS-based viral fingerprinting: current capabilities and challenges [7703-44]

J. D. Driskell, J. L. Abell, R. A. Dluhy, Y.-P. Zhao, R. A. Tripp, The Univ. of Georgia (United States)

770304 Asymmetric GT of social networks [7703-02]

H. Szu, U.S. Army Night Vision \& Electronic Sensors Directorate (United States)

770305 Video surveillance of passengers with mug shots [7703-04]

M. K. Hsu, T. N. Lee, The George Washington Univ. (United States); H. Szu, U.S. Army Night

Vision \& Electronic Sensors Directorate (United States)

\section{WAVELETS LEADERSHIP AWARD}

770306 Recognizing persons by their iris patterns (Invited Paper) [7703-05]

J. Daugman, Cambridge Univ. (United Kingdom)

\section{WAVELETS APPLICATIONS II}

$770307 \quad$ Exploiting iris dynamics (Invited Paper) [7703-06]

C. Hsu, Trident Systems Inc. (United States); H. SzU, U.S. Army Night Vision \& Electronic Sensors

Directorate (United States)

770308 Multiscale directional filtering of noisy InSAR phase images (Invited Paper) [7703-07]

V. M. Patel, Univ. of Maryland, College Park (United States); G. R. Easley, Univ. of Maryland, College Park (United States) and System Planning Corp. (United States); R. Chellappa, Univ. of Maryland, College Park (United States)

\section{ICA UNSUPERVISED LEARNING AWARD}

770309 Proactive learning for artificial cognitive systems (Invited Paper) [7703-13]

S.-Y. Lee, Korea Advanced Institute of Science and Technology (Korea, Republic of) 
$7703 \mathrm{OA}$ Electronic tongue system for remote multi-ion sensing using blind source separation and wireless sensor network (Invited Paper) [7703-09]

W.-Y. Chung, F. R. G. Cruz, Chung Yuan Christian Univ. (Taiwan); H. Szu, The George Washington Univ. (United States); D. G. Pijanowska, M. Dawgul, W. Torbicz, Polish Academy of Sciences (Poland); P. B. Grabiec, B. Jarosewicz, Institute of Electron Technology (Poland); J.-L. Chiang, Chung-Chou Institute of Technology (Taiwan); C. Cheng, K.-C. Chang, L. T. Truc, W.-C. Lin, Chung Yuan Christian Univ. (Taiwan)

$7703 \mathrm{OB} \quad$ Feature extraction and selection strategies for automated target recognition [7703-10] W. N. Greene, Princeton Univ. (United States); Y. Zhang, California Polytechnic Univ. (United States); T. T. Lu, T.-H. Chao, Jet Propulsion Lab. (United States)

7703 OC Border security and surveillance system with smart cameras and motes in a Sensor Web [7703-11]

S. Guler, intuVision, Inc. (United States); T. Cole, Northrop Grumman Information Systems (United States); J. Silverstein, I. Pushee, intuVision, Inc. (United States); S. Fairgrieve, Northrop Grumman Information Systems (United States)

7703 OD Smart sensing surveillance system [7703-12]

C. Hsu, Trident Systems Inc. (United States); K.-D. Chu, U.S. Dept. of Homeland Security

(United States); J. O'Looney, M. Blake, C. Rutar, Trident Systems Inc. (United States)

\section{LEARNING THEORY AND APPLICATIONS}

$7703 \mathrm{OE} \quad$ Learning one-to-many mapping functions for audio-visual integrated perception (Invited Paper) [7703-14]

J.-H. Im, D.-K. Oh, S.-Y. Lee, Korea Advanced Institute of Science and Technology (Korea, Republic of)

7703 OF Multiple optimal learning factors for feed-forward networks [7703-15]

S. S. Malalur, M. T. Manry, The Univ. of Texas at Arlington (United States)

7703 OG CORDIC algorithms for SVM FPGA implementation [7703-16]

J. Gimeno Sarciada, H. Lamela Rivera, M. Jiménez, Univ. Carlos III de Madrid (Spain)

\section{NANO-ENGINEERING}

$7703 \mathrm{O}$ CONTACT: sensors for aerospace and Fano-resonance photonic crystal cavities [7703-18] F. J. Agee, Rice Univ. (United States); W. Zhou, The Univ. of Texas at Arlington (United States); A. Chow, Rice Univ. (United States)

7703 0J Nano-photonics: past and present [7703-19]

H. Szu, U.S. Army Night Vision \& Electronic Sensors Directorate (United States)

7703 OK The role of extensive variables in nanoscience [7703-20]

J. E. Gray, F. Santiago, Naval Surface Warfare Ctr. Dahlgren Div. (United States) 
$7703 \mathrm{OL} \quad$ Watermarking strategies for IP protection of micro-processor cores [7703-21]

L. Parrilla, E. Castillo, Univ. of Granada (Spain); U. Meyer-Bäse, Florida State Univ. (United States); A. García, D. González, Univ. of Granada (Spain); E. Todorovich, E. Boemo, Univ. Autónoma de Madrid (Spain); A. Lloris, Univ. of Granada (Spain)

$7703 \mathrm{OM} \quad$ Nios II hardware acceleration of the epsilon quadratic sieve algorithm [7703-22] U. Meyer-Bäse, G. Botella, Florida State Univ. (United States); E. Castillo, A. García, Univ. of Granada (Spain)

770300 Optimization of a hardware implementation for pulse coupled neural networks for image applications [7703-24]

J. Gimeno Sarciada, H. Lamela Rivera, Univ. Carlos III de Madrid (Spain); C. Warde, Massachusetts Institute of Technology (United States)

$7703 \mathrm{OP} \quad$ Design and simulation of optoelectronic complementary dual neural elements for realizing a family of normalized vector 'equivalence-nonequivalence' operations [7703-25]

V. G. Krasilenko, A. I. Nikolsky, A. A. Lazarev, T. E. Magas, Open International Univ. of Human Development (Ukraine)

BIOMEDICAL WELLNESS AWARD FOR APPLYING COMPUTATIONAL INTELLIGENCE TO IMAGE DIAGNOSIS

$77030 Q \quad$ Medical diagnosis imaging systems: image and signal processing applications aided by fuzzy logic (Invited Paper) [7703-26]

Y. Hata, Univ. of Hyogo (Japan)

BIOMEDICAL WELLNESS APPLICATIONS

$7703 \mathrm{OR} \quad$ Optical determination of cardiovascular health at a distance [7703-27]

M. Farley, H. Szu, J. P. Reynolds, U.S. Army Night Vision \& Electronic Sensors Directorate (United States)

7703 OS Full-field, nonscanning, optical imaging for perfusion indication [7703-29]

N.-Y. Chou, L. W. Winchester, Jr., W. J. Naramore, M. S. Alley, A. J. Lesnick, CW Optics, Inc. (United States)

7703 OT Can we detect influenza? [7703-28]

P. Dolan, H. SzU, U.S. Army Night Vision \& Electronic Sensors Directorate (United States)

WELLNESS SMART SENSORS

7703 OU Computer-aided diagnosis and lipidomics analysis to detect and treat breast cancer [7703-30]

A. Meyer-Bäse, Florida State Univ. (United States); F. Retter, Univ. of Saarbrücken (Germany); F. Steinbrücker, Univ. of Bonn (Germany); R. Görke, Univ. of Karlsruhe (Germany); B. Burgeth, Univ. of Saarbrücken (Germany); T. Schlossbauer, Univ. of Munich (Germany) 
7703 OV Denoising of x-ray imagery with spatially varying estimates of noise variance [7703-31] S. P. Kozaitis, Florida Institute of Technology (United States)

7703 OW Comparative analysis of filtered back-projection algorithms for optoacoustic imaging [7703-32]

R. Gutiérrez, H. Lamela, D. Gallego, A. Martín, Univ. Carlos III de Madrid (Spain);

A. A. Oraevsky, Fairway Medical Technologies, Inc. (United States)

\section{SYSTEM BIOLOGY PIONEER AWARD}

7703 0X The hidden impact of inter-individual genomic variations on cellular function (Invited Paper) [7703-34]

C. Georgescu, H. Bolouri, California Institute of Technology (United States)

\section{SYSTEM BIOLOGY}

7703 OY Novel systems biology and computational methods for lipidomics [7703-35]

A. Meyer-Bäse, Florida State Univ. (United States); S. Lespinats, CEA, LIST, Multisensor Intelligence and Machine Learning Lab. (France)

$7703 \mathrm{OZ} \quad$ Variable patch sizes for normalized cross correlation in image pairs [7703-36]

J. Wang, M. A. Pratt, C. H. Chu, Univ. of Lovisiana at Lafayette (United States)

770310 A subspace learning approach to evaluating the performance of image fusion algorithms [7703-37]

K. A. Byrd, U.S. Army RDECOM CERDEC NVESD (United States) and Howard Univ. (United States); H. Szu, U.S. Army RDECOM CERDEC NVESD (United States); M. Chouikha, Howard Univ. (United States)

\section{SMART SENSORS APPLICATIONS}

770312 Recognizing foreground-background interaction [7703-39]

J. Jenkins, H. Szu, U.S. Army Night Vision \& Electronic Sensors Directorate (United States)

770314 Study on the technique of distinguishing rock from coal based on statistical analysis of fast Fourier transform [7703-42]

X. Li, T. GU, North China Institute of Science and Technology (China)

770315 Evaluation model for the implementation results of mine law based on neural network [7703-43]

T. GU, X. Li, North China Institute of Science and Technology (China)

770316 Biomimetic novelty detection (Invited Paper) [7703-03]

L. W. Ma, Univ. of Wisconsin-Madison (United States); H. Szu, US Army RDECOM CERDEC NVESD (United States)

Author Index 


\title{
Conference Committee
}

\author{
Symposium Chair
}

Michael T. Eismann, Air Force Research Laboratory (United States)

Symposium Cochair

William Jeffrey, HRL Laboratory, LLC (United States)

Conference Chairs

Harold H. Szu, U.S. Army Night Vision \& Electronic Sensors Directorate (United States)

F. Jack Agee, Rice University (United States)

\section{Conference Cochairs}

Fredric M. Ham, Florida Institute of Technology (United States)

Toshio Fukuda, Nagoya University (Japan)

Tzyy-Ping Jung, University of California, San Diego (United States)

Soo-Young Lee, Korea Advanced Institute of Science and Technology (Korea, Republic of)

Kitt C. Reinhardt, Air Force Office of Scientific Research (United States)

Takeshi Yamakawa, Kyushu Institute of Technology (Japan)

\section{Program Committee}

Shun-ichi Amari, RIKEN (Japan)

C. Sidney Burrus, Rice University (United States)

Chang Wen Chen, University at Buffalo (United States)

Henry Chu, University of Lovisiana at Lafayette (United States)

Wen-Yan D. Chung, Chung Yuan Christian University (Taiwan)

Andrzej S. Cichocki, Telcordia Technologies, Inc. (United States)

Ronald R. Coifman, Yale University (United States)

Ronald A. DeVore, University of South Carolina (United States)

Qian Du, Mississippi State University (United States)

Mark Girolami, University of Glasgow (United Kingdom)

Norden E. Huang, National Central University (Taiwan)

Charles C. Hsu, Trident Systems Inc. (United States)

Phillip Q. Hwang, National Imagery \& Mapping Agency (NIMA) (United States)

Horacio Lamela Rivera, Universidad Carlos III de Madrid (Spain)

Joseph Landa, BriarTek, Inc. (United States)

Te-Won Lee, University of California, San Diego (United States)

William W. Liou, Western Michigan University (United States) 
Kevin W. Lyons, National Institute of Standards and Technology (United States)

Shoji Makino, NTT Communication Science Laboratory (Japan)

Anke D. Meyer-Bäse, Florida State University (United States)

Uwe Meyer-Bäse, Florida State University (United States)

Francesco C. Morabito, Universitá di Reggio Calabria (Italy)

Erkki Oja, Helsinki University of Technology (Finland)

Dennis W. Prather, University of Delaware (United States)

Hairong Qi, The University of Tennessee (United States)

Mark J. T. Smith, Purdue University (United States)

Wim Sweldens, Alcatel-Lucent Bell Laboratory (United States)

Mladen V. Wickerhauser, Washington University in St. Louis (United

States)

Olaf Wolkenhaver, Universität Rostock (Germany)

Donald C. Wunsch II, Missouri University of Science and Technology (United States)

Ning Xi, Michigan State University (United States)

Fred Yang, Missioncate Hospital Group (Taiwan)

Session Chairs

1 Wavelet Pioneer Award

Ronald R. Coifman, Yale University (United States)

Harold H. Szu, U.S. Army Night Vision \& Electronic Sensors Directorate (United States)

2 Wavelets Applications I

Ronald R. Coifman, Yale University (United States)

Harold H. Szu, U.S. Army Night Vision \& Electronic Sensors Directorate (United States)

3 Wavelets Leadership Award

Harold H. Szu, U.S. Army Night Vision \& Electronic Sensors Directorate (United States)

Thomas Hopper, Federal Bureau of Investigation (United States)

$4 \quad$ Wavelets Applications II

Harold H. Szu, U.S. Army Night Vision \& Electronic Sensors Directorate (United States)

$5 \quad$ ICA Unsupervised Learning Award

Tzyy-Ping Jung, University of California, San Diego (United States)

Soo-Young Lee, Korea Advanced Institute of Science and Technology

(Korea, Republic of)

6 Unsupervised Learning and ICA

Tzyy-Ping Jung, University of California, San Diego (United States)

Mark Girolami, University of Glasgow (United Kingdom) 
$7 \quad$ Learning Theory and Applications

Soo-Young Lee, Korea Advanced Institute of Science and Technology (Korea, Republic of)

Takeshi Yamakawa, Kyushu Institute of Technology (Japan)

$8 \quad$ Nano-engineering Award

Kitt C. Reinhardt, Air Force Office of Scientific Research (United States)

F. Jack Agee, Rice University (United States)

$9 \quad$ Nano-Engineering

F. Jack Agee, Rice University (United States)

Kitt C. Reinhardt, Air Force Office of Scientific Research (United States)

10 Smart Sensor Systems and Miniaturization

Uwe Meyer-Bäse, Florida State University (United States)

Wen-Yan D. Chung, Chung Yuan Christian University (Taiwan)

11 Biomedical Wellness Award for Applying Computational Intelligence to Image Diagnosis

Takeshi Yamakawa, Kyushu Institute of Technology (Japan)

Soo-Young Lee, Korea Advanced Institute of Science and Technology (Korea, Republic of)

12 Biomedical Wellness Applications

Takeshi Yamakawa, Kyushu Institute of Technology (Japan)

Soo-Young Lee, Korea Advanced Institute of Science and Technology (Korea, Republic of)

13 Wellness Smart Sensors

Yutaka Hata, University of Hyogo (Japan)

Takeshi Yamakawa, Kyushu Institute of Technology (Japan)

14 System Biology Pioneer Award

Olaf Wolkenhaver, Universität Rostock (Germany)

Harold H. Szu, U.S. Army Night Vision \& Electronic Sensors Directorate (United States)

15 System Biology

Olaf Wolkenhauer, University of Rostock (Germany)

Harold H. Szu, U.S. Army Night Vision \& Electronic Sensors Directorate (United States)

16 Smart Sensors Applications

Kenneth A. Byrd, Howard University (United States)

Henry Chu, University of Lovisiana at Lafayette (United States) 
Downloaded From: https://www.spiedigitallibrary.org/conference-proceedings-of-spie on 25 Apr 2023

Terms of Use: https://www.spiedigitallibrary.org/terms-of-use 


\section{Introduction}

The year 2010 marks the eighth anniversary of the SPIE conference on Independent Component Analysis, Wavelets, Neural Networks, Biosystems and Nanoengineering. The SPIE Defense Security and Sensing (DSS) Symposium has provided our community with the proper venue for not only information exchange, but also education through shortcourses and networking through various hospitality events. The symposium itself, boasts over 500 exhibiting vendors and talks given by over 6000 scientists and engineers worldwide. Our conference is, among 30, relatively small, but has a reputation of producing some of the most cited works in the disciplines covered. Onsite publication and dissemination of the Conference Proceedings has proven useful time and time again providing a timely dissemination of on-going research in smart sensors, processing and endto-end systems to libraries worldwide.

Being co-chairs, we often face questions about our goals and focus for the future of the conference series. To state the question plainly, how has the conference endured, and how can it continue to endure and evolve in an uncertain future? The answer lies partly in the following secret: We have adapted a workable system tested by the Nobel Foundation for over half a century-passing the baton of honor.... "The past award recipients shall determine the new awardees." The role SPIE and the co-chairs serve is to act as facilitators for the decision process. A major difference between the systems is a lack of recourse in supporting the awardees. Thus we have improvised a temporary win-win-win solution: in order to prepare the interdisciplinary audience, state of the art knowledge is disseminated by both past and present award recipients, who are encouraged to teach short courses at the meetings.

The ICA conference, now in its 17th year with SPIE, was established to address our desire to learn from Mother Nature. The question of where to begin is a difficult one and thus we began slowly, building year by year, learning from one another. This year the results have been impressive. From the 2010 Wavelet Pioneer Award Recipient Prof. Jan-Olov Strömberg (Royal Institute of Technology), we learn how to "steal a smart algorithm" from the ear-eye like Wavelet transform. In the same theme, we follow brain-like neural nets seeking to learn, from observable effects, the underlying hidden causes explained by the 2010 recipient of the Unsupervised Learning Neural Network Independent Component Analyses (ICA): To $\mathrm{Be}$ Announced on-site. After a decade, some are ready for the "implementation" and "test and evaluation" of these advances. With this in mind, we encourage you to consider the $\mathrm{NIH}$-phobia problem explained by our 2010 Biomedical Wellness Award recipient Prof. Yutaka Hata, (University of Hyogo). We introduce so-called "Nano-Engineering," as elucidated by our 2010 NanoEngineering Pioneer Award recipient Prof. Diana Huffaker (University of California, Los Angeles). Nano-engineers can take advantage of the transitional nanometer 
regime, which falls between classical physics and quantum mechanics and is technically defined as $10^{-9} \mathrm{~m}=10$ angstrom $=20$ hydrogen atoms. Finally, we are ready to emulate the most robust, and perhaps most efficient field in its own right, System Biology, as elucidated by our 2010 Pioneer Award recipient Dr. Hamid Bolouri (Caltech) during the last day of our end-to-end program.

We wish to thank all of 2009 recipients, who headed the selection process for this year's recipients: Prof. Ronald Coifman, Prof. Mark Girolami, Prof. Tzyy-Ping Jung, Dr. Robert Shull, Takashi Yamakawa and Prof. Olad Wolkenhaver. The Conference would not be a success without you and your unselfish contributions.

We would also like to thank the SPIE technical support staff and last but certainly not least, I would like to thank the members of the program committee.

\section{Harold Szu F. Jack Agee}

